\title{
Iodoform-Blended Portland Cement for Dentistry
}

\author{
Qiu Li ${ }^{1}$, Andrew D. Deacon ${ }^{2}$ and Nichola J. Coleman ${ }^{2, *}$ \\ 1 State Key Laboratory of Silicate Materials for Architectures, Wuhan University of Technology, Wuhan 430070, \\ China; qiu-li@whut.edu.cn \\ 2 Faculty of Engineering and Science, University of Greenwich, Chatham Maritime, Kent ME4 4TB, UK; \\ andrew.deacon@gre.ac.uk \\ * Correspondence: n.coleman@gre.ac.uk; Tel.: +44-208-331-9825
}

Received: 17 August 2020; Accepted: 30 September 2020; Published: 7 October 2020

\begin{abstract}
Portland cement-based formulations blended with radiopacifying agents are popular endodontic materials for various root filling and pulp capping applications. Iodoform $\left(\mathrm{CHI}_{3}\right)$ is an alternative candidate radiopacifier whose impact on the setting, bioactivity, antimicrobial properties and cytotoxicity of white Portland cement were evaluated in this study. Isothermal conduction calorimetry and ${ }^{29}$ Si magic angle spinning nuclear magnetic resonance spectroscopy (MAS NMR) showed that $20 \mathrm{wt} \%$ iodoform had no significant impact on the kinetics of cement hydration with respect to the formation of the major calcium silicate hydrate (C-S-H) gel product (throughout the 28-day observation). Conversely, transmission electron microscopy demonstrated that iodine was incorporated into the ettringite $\left(\mathrm{Ca}_{6} \mathrm{Al}_{2}\left(\mathrm{SO}_{4}\right)_{3}(\mathrm{OH})_{12} \cdot 26 \mathrm{H}_{2} \mathrm{O}\right)$ product phase. Both iodoform-blended and pure Portland cements exhibited comparable biocompatibility with MG63 human osteosarcoma cells and similar bioactivity with respect to the formation of a hydroxyapatite layer upon immersion in simulated body fluid. By virtue of their high alkalinity, both cements inhibited the growth of Staphylococcus aureus, Pseudomonas aeruginosa and Escherichia coli. However, in all cases, iodoform enhanced the antimicrobial effect and significantly reduced the minimum bactericidal concentration of the cement. In conclusion, iodoform offers antimicrobial advantages in Portland cement-based formulations where oral biofilm formation threatens the success of root filling materials and dentine substitutes. The reactivity with the calcium aluminosulfate components of the hydrating cement matrix warrants further research to understand the long-term stability of the cement matrix in the presence of iodoform.
\end{abstract}

Keywords: calcium silicate cement; Portland cement; endodontic bioceramic; cement hydration; iodoform; radiopacifier; magic angle spinning nuclear magnetic resonance spectroscopy; isothermal conduction calorimetry; Fourier transform infrared spectroscopy; antimicrobial

\section{Introduction}

Commercial calcium silicate dental materials based upon Portland cement and its constituents are popular options for a variety of dentine substitution, root-end filling and pulp capping indications [1-5]. These cements are 'bioactive' in that they are capable of forming hydroxyapatite on their surfaces in vivo to support bone, dentine, cementum, periapical tissue and pulp healing [1-5].

The composition and properties of Portland cement-based endodontic materials are widely reported in the current literature [1-5]. Briefly, Portland cement comprises five phases; alite (tricalcium silicate, $\mathrm{Ca}_{3} \mathrm{SiO}_{5}$ ), belite ( $\beta$-dicalcium silicate, $\mathrm{Ca}_{2} \mathrm{SiO}_{4}$ ), aluminate (tricalcium aluminate, $\mathrm{Ca}_{3} \mathrm{Al}_{2} \mathrm{O}_{6}$ ), ferrite (tetracalcium aluminoferrite, $\mathrm{Ca}_{2}(\mathrm{Al} / \mathrm{Fe})_{2} \mathrm{O}_{5}$ ), and gypsum (calcium sulfate dihydrate, $\mathrm{CaSO}_{4} \cdot 2 \mathrm{H}_{2} \mathrm{O}$ ) that react with water to form an adhesive paste that sets into a hardened mass within a few hours and continues to gain compressive strength over a period of weeks [1-5]. Alite and belite hydrate to form a nonstoichiometric nanoporous calcium silicate hydrate (C-S-H) gel matrix 
and hexagonal crystals of calcium hydroxide (aka portlandite). Aluminate and gypsum react with water to form ettringite $\left(\mathrm{AFt}, 6 \mathrm{CaO} \cdot \mathrm{Al}_{2} \mathrm{O}_{3} \cdot 3 \mathrm{SO}_{3} \cdot 32 \mathrm{H}_{2} \mathrm{O}\right)$ which subsequently decomposes to the thermodynamically more stable monosulfate $\left(\mathrm{AFm}, 4 \mathrm{CaO} \cdot \mathrm{Al}_{2} \mathrm{O}_{3} \cdot \mathrm{SO}_{3} \cdot 13 \mathrm{H}_{2} \mathrm{O}\right)$ phase [5]. Ferrite reacts similarly to produce Fe-substituted AFt and AFm phases [5]. It should be noted that hydraulic calcium silicate dental cements differ from industrial ordinary Portland cements in that their heavy metal content is lower and the particle sizes are smaller [1-5]. Also, some calcium silicate dental cements, such as Biodentine ${ }^{\circledR}$ and Bioaggregate ${ }^{\mathrm{TM}}$, are exclusively formulated from alite and belite and do not contain aluminate, ferrite, and gypsum [1-5].

Endodontic materials are required to possess a minimum radiopacity equivalent to $3 \mathrm{~mm} \mathrm{Al} \mathrm{[6],}$ which is achieved by dry-blending the cement with radiopaque barium sulfate or metal oxide compounds of bismuth, zirconium, tantalum, or niobium [1-5]. A range of alternative candidate radiopacifying agents, including $\mathrm{TiF}_{4}, \mathrm{CaWO}_{4}, \mathrm{Yb}_{2} \mathrm{O}_{3}, \mathrm{YbF}_{3}$ and $\mathrm{CHI}_{3}$, has also been proposed [7-12]. Of these, $\mathrm{CHI}_{3}$ (iodoform) is a common constituent of commercial calcium hydroxide-based pulp capping formulations (e.g., Vitapex ${ }^{\circledR}$ (Neo Dental International Inc., Federal Way, WA, USA) and Metapex (Meta Biomed, Colmar, PA, USA)). Iodoform is also added to epoxy resin endodontic sealers to confer radiopacity and antimicrobial properties [13-15].

In vitro, animal and human studies indicate that iodoform is adequately biocompatible and sufficiently radiopaque at $20 \mathrm{wt} \%$ addition to Portland cement to comply with the current regulatory standards for root filling materials (i.e., ISO 6876:2012 [6] and ANSI/ADA specification \#57 [16]) [7,17-23]. At present, very little is known of the impact of iodoform on the complex hydration and setting reactions of Portland cement. Accordingly, the objectives of this study were to evaluate the effect of $20 \mathrm{wt} \%$ addition of iodoform on the hydration, bioactivity, antimicrobial properties and cytotoxicity of white Portland cement (WPC).

The impact of iodoform on the kinetics of the early hydration and setting reactions of the WPC (up to $70 \mathrm{~h}$ ) were monitored by isothermal conduction calorimetry. The microstructures of the cements were observed by transmission electron microscopy (TEM) with energy dispersive $X$-ray spectroscopy (EDX) prior to and following the major exothermic reactions (at 3 and $6 \mathrm{~h}$ ). The longer term development of the hydrated phases within the pure and iodoform-blended cement pastes was evaluated by powder $\mathrm{X}$-ray diffraction analysis (XRD) and ${ }^{27} \mathrm{Al}$ and ${ }^{29} \mathrm{Si}$ magic angle spinning nuclear magnetic resonance spectroscopy (MAS NMR) at 7, 14 and 28 days. The bioactivities of the cements were determined in vitro by immersion in simulated body fluid and a pseudo-second-order kinetic model was used to compare the rates of formation of hydroxyapatite on their surfaces [24,25]. The impact of iodoform on the biocompatibility of the cement was assessed using human MG63 osteosarcoma cells and its influence on antimicrobial properties was evaluated using the common pathogens Staphylococcus aureus, Pseudomonas aeruginosa and Escherichia coli.

\section{Results}

\subsection{Isothermal Conduction Calorimetry}

The rates of heat evolution (per gram of cement powder) of the pure (WPC) and iodoform-blended (WPC-I) white Portland cement are plotted in Figure 1 and compare well with those of other Portland cement-based mixes reported in the literature [26-30]. The setting of Portland cements is governed by a complex sequence of exothermic dissolution and precipitation reactions, during which the initial heat evolved within the first $24 \mathrm{~h}$ is principally dictated by the formation of ettringite and the hydration of alite (which reacts more rapidly and is more abundant than belite). 


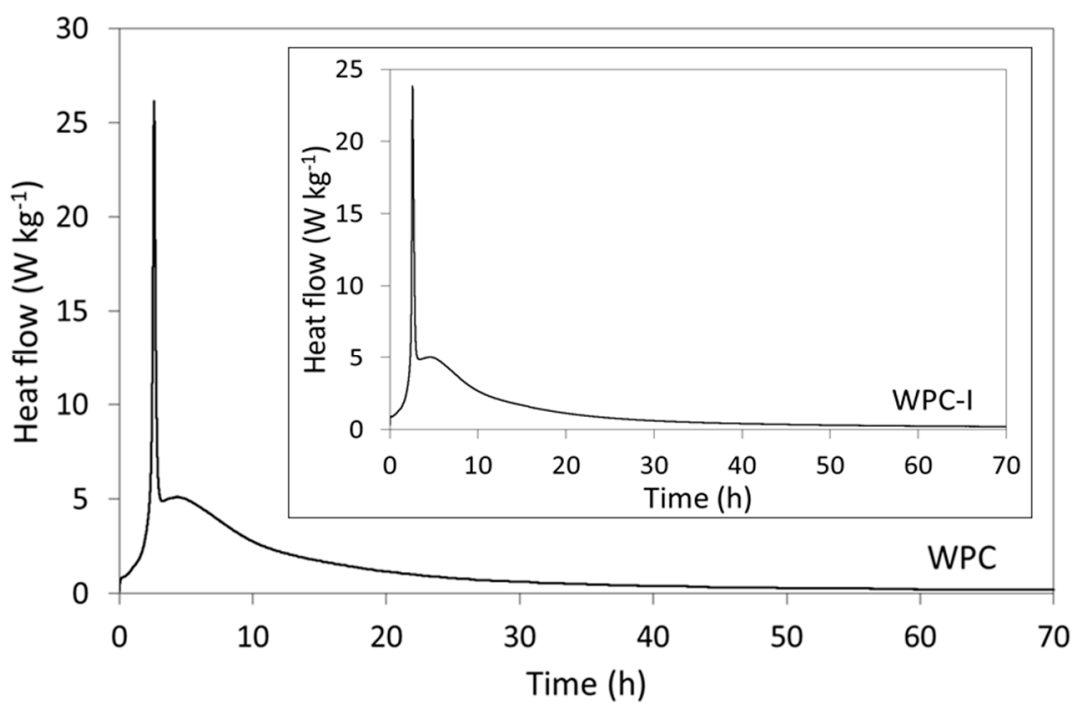

Figure 1. Rates of heat evolution from WPC and WPC-I during hydration at $37.5^{\circ} \mathrm{C}$.

On mixing with water, the wetting of the cement grains, dissolution of hydroxide, sulfate and aluminate species, and the initial precipitation of early hydrates gave rise to a strongly exothermic signal within the first few minutes. This initial signal was not recorded in the thermograms shown in Figure 1, as the calorimeter required $15 \mathrm{~min}$ to equilibrate. The thermograms of WPC and WPC-I commenced during the 'induction' (or dormant) period which persisted up to $1 \mathrm{~h} 30 \mathrm{~min}$ after mixing, during which the dissolution and precipitation reactions were slow and heat evolution was low [28]. The subsequent intense exotherm, observed after approximately $2 \mathrm{~h} 45 \mathrm{~min}$ for both samples, was attributed to renewed ettringite formation and generated maximum heat flows of $25.8 \pm 0.9$ and $23.7 \pm 0.9 \mathrm{~mW} \mathrm{~g}^{-1}$ for WPC and WPC-I, respectively. The ensuing acceleration phase was denoted by an increase in heat flow that was largely dictated by the rate of precipitation of the C-S-H gel. The respective maximum rates of heat evolution during the acceleratory period for WPC and WPC-I were $5.1 \pm 0.7 \mathrm{~kg}^{-1}$ ( $4 \mathrm{~h} 40 \mathrm{~min}$ after mixing) and $5.0 \pm 0.7 \mathrm{~W} \mathrm{~kg}^{-1}$ ( $5 \mathrm{~h}$ after mixing). The deceleratory stage which followed was characterised by a steady reduction in hydration rate as the cement matrix consolidated and the reactions became diffusion controlled [28].

\subsection{Transmission Electron Microscopy}

TEM bright field images were taken of WPC and WPC-I to evaluate any differences in the microstructures of the cements immediately after the exotherm arising from renewed ettringite formation $($ at $3 \mathrm{~h}$ ) and after the maximum heat evolution during the acceleratory period (at $6 \mathrm{~h}$ ) (Figure 2). After $3 \mathrm{~h}$, the cement microstructures of both WPC and WPC-I were characterised by fibrillar C-S-H gel intermixed with lath-like crystals of ettringite of varying sizes (Figure 2). The ettringite crystals in the unblended WPC sample were considerably smaller and more numerous than those of the iodoform-blended paste after curing for $3 \mathrm{~h}$. Six hours after mixing, following the maximum heat flow during the acceleratory period, an increase in the proportion and density of the C-S-H gel was observed and the ettringite crystals were of similar sizes and dimensions in both cement pastes ( $100 \mathrm{~nm}$ in width with aspect ratios greater than 10). 


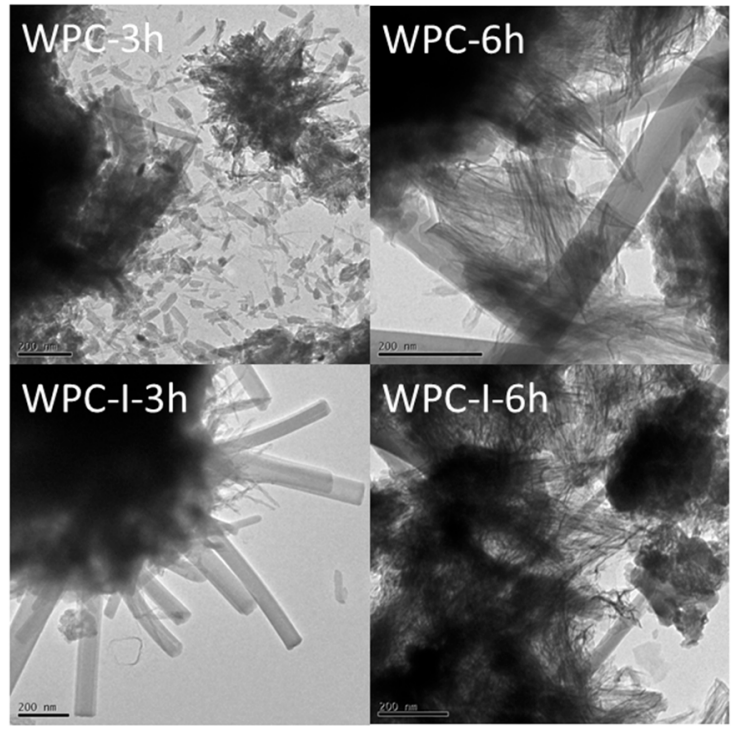

Figure 2. TEM images of WPC and WPC-I following hydration for 3 and $6 \mathrm{~h}$.

Atomic ratio plots of I/Ca against Al/Ca from TEM-EDX analysis of the ettringite phase in the iodoform-blended cement pastes at 3 and $6 \mathrm{~h}$ (WPC-I-3 h and WPC-I- $6 \mathrm{~h}$, respectively) are shown in Figure 3. These data indicate that some iodine was released from the iodoform and nonstoichiometrically incorporated into the ettringite phase (as evidenced by the low linear correlation between I/Ca and $\mathrm{Al} / \mathrm{Ca}$ ). No correlation was observed between I/Ca and Si/Ca for the C-S-H gel phase, indicating that iodine was not taken up into the structure of the C-S-H gel to any appreciable extent. However, the variable I/Ca ratio indicates that iodoform, and/or possibly other released iodine species, were adsorbed onto the C-S-H gel phase.
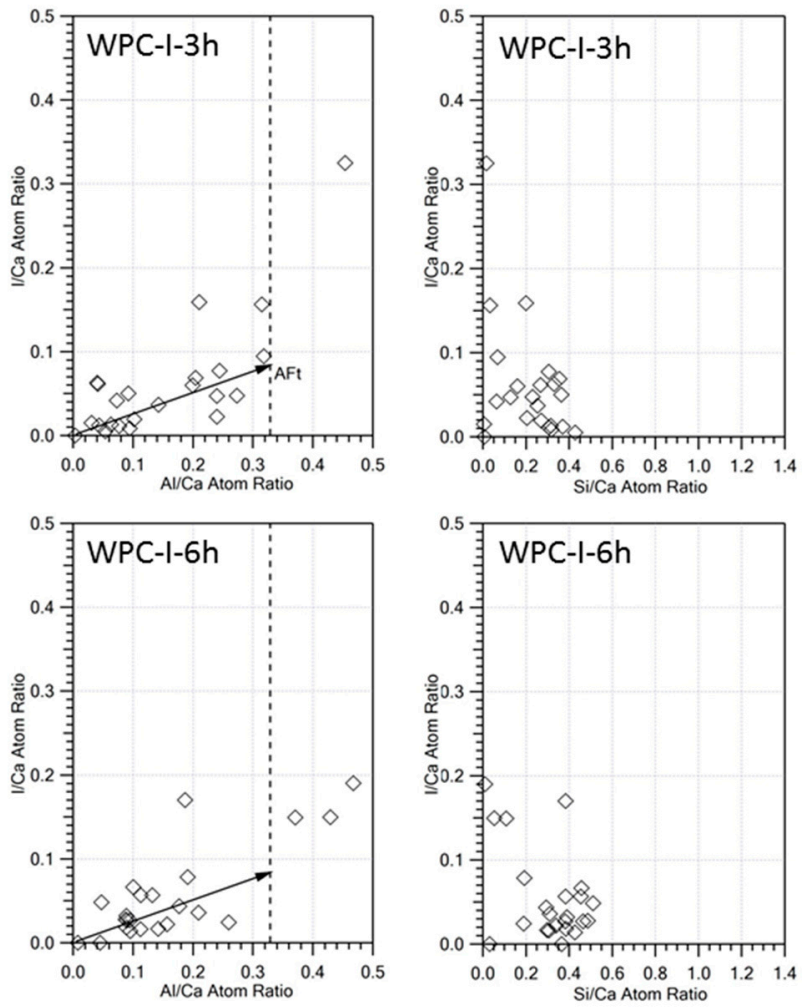

Figure 3. I/Ca against $\mathrm{Al} / \mathrm{Ca}$ and $\mathrm{I} / \mathrm{Ca}$ against $\mathrm{Si} / \mathrm{Ca}$ atomic ratio plots of TEM-EDX analyses of the hydrated phases present WPC-I following hydration for 3 and $6 \mathrm{~h}$. 


\subsection{Powder X-ray Diffraction Analysis}

Powder XRD patterns are shown in Figure 4 of the pure and iodoform-blended cement pastes after hydration for 7,14 and 28 days. These qualitative powder XRD data show that the reflections for alite and belite persisted throughout the 28-day observation period, yet diminished in intensity, indicating that the cements were not fully hydrated within 28 days. The evolution of the very strong reflections of portlandite (at 18.1,28.8,34.2, and $47.2^{\circ}$ ) is clearly observed in the diffractograms of both WPC and WPC-I, and ettringite is evident from the weaker peaks at 9.1, 15.8, and 22.9 ${ }^{\circ}$ [25]. The major C-S-H gel product was poorly crystalline, and its presence is denoted by cambers in the baseline in the $2 \theta$ ranges $10-15^{\circ}$ and $25-35^{\circ}[27]$.

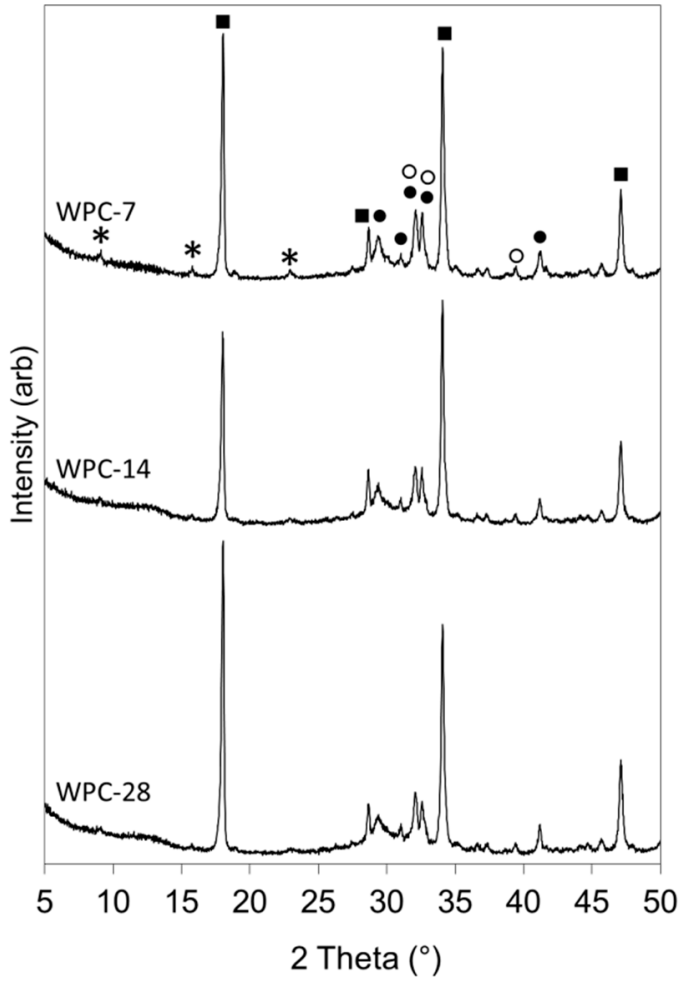

(a)

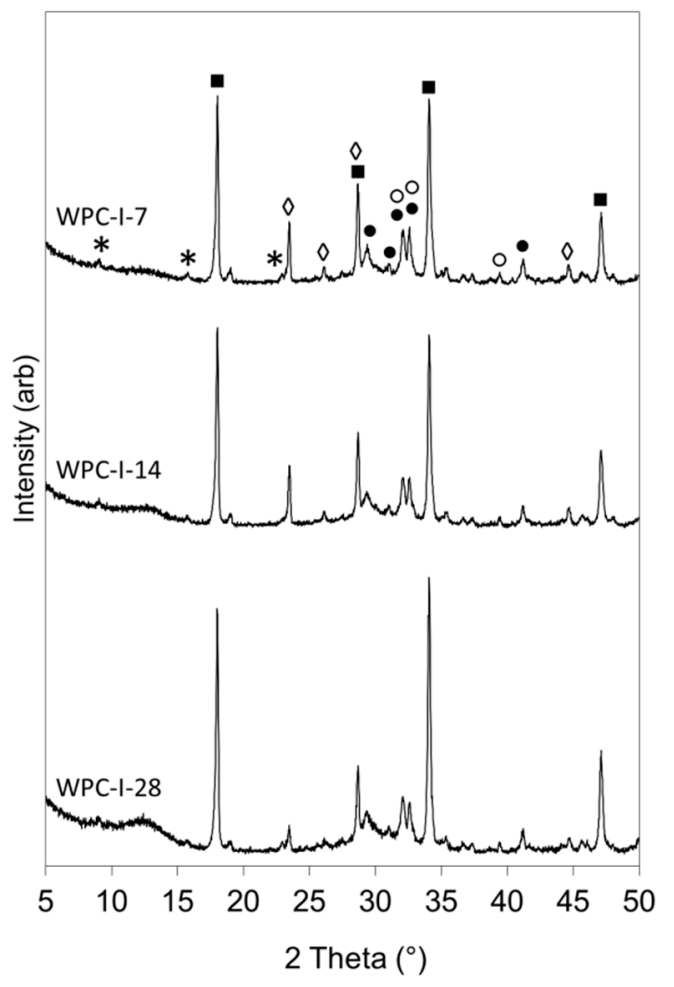

(b)

Figure 4. Powder XRD patterns of (a) WPC and (b) WPC-I following hydration for 7, 14 and 28 days. (Key: • alite; $\bigcirc$ belite; ${ }^{*}$ ettringite; $\mathbf{\square}$ portlandite; $\diamond$ iodoform).

The relative intensities of the reflections of iodoform in the XRD patterns of sample WPC-I (at 23.5, 26.1, 28.7, and $44.7^{\circ}$ ) diminished as a function of time (Figure $4 \mathrm{~b}$ ). Reflections from iodoform indicate that this phase was present as discreet crystallites within the cement matrix rather than individually dispersed molecules. As hydration progressed, the reduction in intensity of the iodoform reflections may have arisen from the dissolution and dispersion of the crystallites as the microstructure of the cement developed or could indicate that the iodoform was undergoing chemical reaction in the alkaline environment within the cement matrix. Throughout the 28-day observation period, no evidence was found for the formation of any additional iodine-bearing constituents, or any other phases that are atypical of Portland cements hydrated under ambient conditions.

\section{4. ${ }^{27}$ Al and ${ }^{29}$ Si Magic Angle Spinning Nuclear Magnetic Resonance Spectroscopy}

${ }^{27} \mathrm{Al}$ and ${ }^{29} \mathrm{Si}$ MAS NMR techniques are sensitive to the local chemical environment of the aluminate and silicate tetrahedra within the anhydrous and hydrated product phases of Portland 
cements $[26,27,29,31-34]$. These techniques are complementary to XRD for the structural determination of poorly crystalline and amorphous phases as they do not rely on long-range molecular order.

${ }^{27}$ Al MAS NMR spectroscopy is used to determine the coordination environment of aluminium species in cements. Aluminium in octahedral coordination, such as those in the AFt and AFm phases, gives rise to resonances in the approximate chemical shift range 20 to $-10 \mathrm{ppm}$; whereas tetrahedral aluminate species, such as those substituted into alite, belite and C-S-H gel, resonate between 100 and $50 \mathrm{ppm}$ [34]. Signals arising from the anhydrous aluminate and ferrite phases are not present in the ${ }^{27} \mathrm{Al}$ MAS NMR spectra of Portland cements as they are extensively line-broadened. The intensity of the resonances in the ${ }^{27} \mathrm{Al}$ MAS NMR spectra are not directly proportional to the relative concentrations of the aluminium species from which they arise owing to the quadrupolar nature of the ${ }^{27} \mathrm{Al}$ nucleus [34].

The ${ }^{27} \mathrm{Al}$ MAS NMR spectrum of the anhydrous cement and those of WPC and WPC-I following hydration for 7, 14 and 28 days are presented in Figure 5. In these spectra, 'spinning side bands' are harmonics that result from the modulation of the magnetic field at the spinning frequency and are denoted by asterisks.

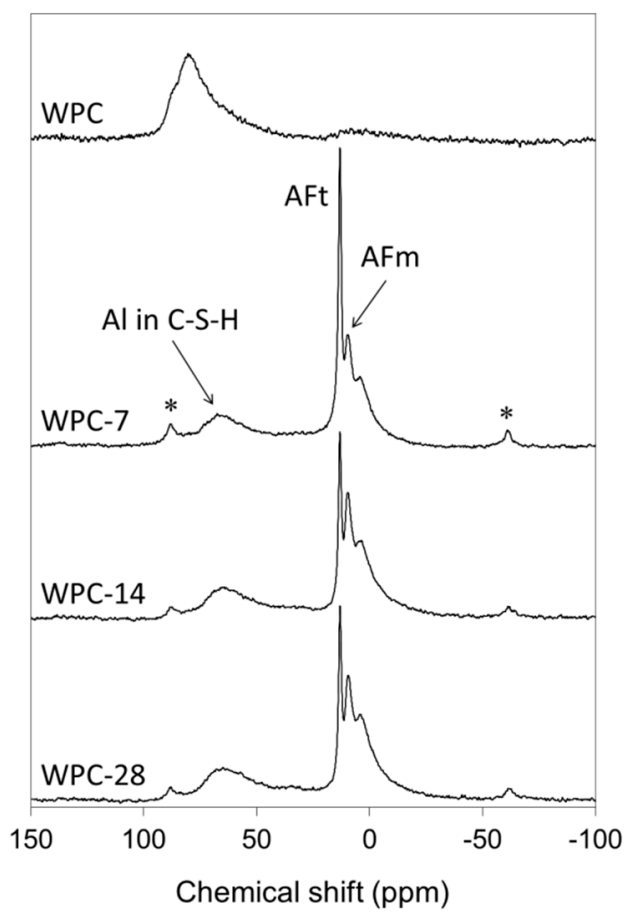

(a)

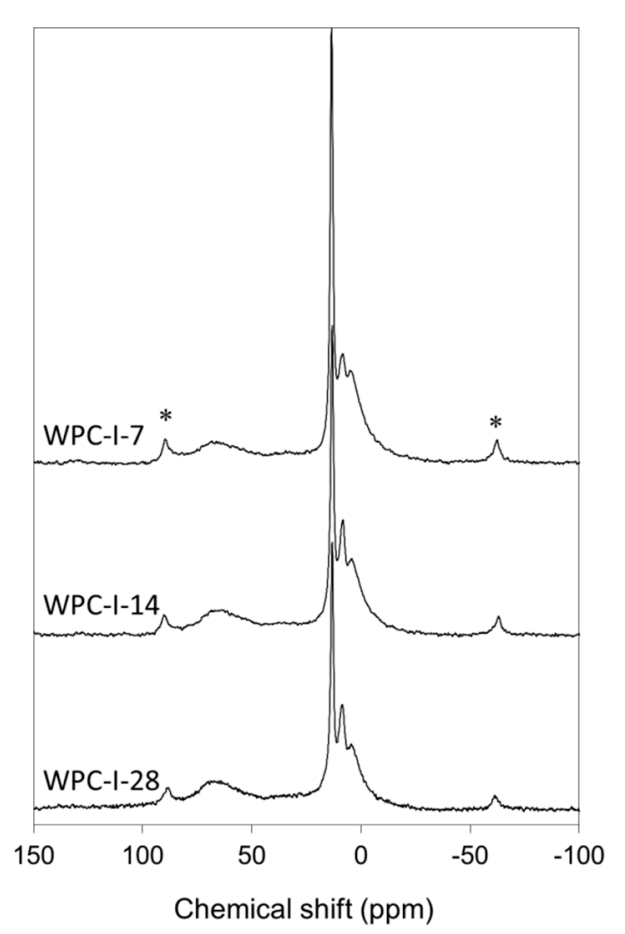

(b)

Figure 5. ${ }^{27} \mathrm{Al}$ MAS NMR spectra of (a) WPC and (b) WPC-I following hydration for 7, 14 and 28 days.

The spectrum of anhydrous white Portland cement (labelled WPC in Figure 5a) comprises a broad asymmetric resonance at approximately $82 \mathrm{ppm}$ that arose from isolated aluminate tetrahedra substituted into alite and belite [35]. As hydration proceeded, unresolved resonances of octahedral aluminate species in ettringite (AFt) and monosulfate (AFm) appeared at 13.2 and $11.0 \mathrm{ppm}$, respectively, along with a third octahedral aluminate signal at $5.0 \mathrm{ppm}$ assigned to an amorphous aluminate hydrate phase [36]. Between 7 and 28 days, the reduction in the intensity of the AFt signal relative to that of AFm is indicative of the progressive conversion of ettringite to the more thermodynamically stable monosulfate phase.

The ${ }^{27} \mathrm{Al}$ MAS NMR spectra of the hydrating WPC-I sample (Figure $5 b$ ) resemble those of the unblended WPC paste (Figure 5a) with respect to the presence of signals arising from substituted aluminate tetrahedra in the C-S-H gel phase and octahedral aluminate in the AFt, AFm and amorphous aluminate hydrate phases. However, the AFt signals in the spectra of the iodoform-blended cement are 
more intense than those of the plain WPC paste and the rate of conversion of ettringite to monosulfate is slower.

${ }^{29} \mathrm{Si}$ MAS NMR spectroscopy is used quantitatively to determine the degree of hydration of the silicate phases in Portland cements, and also to estimate the mean length of the aluminosilicate chains (MCL) and the extent of aluminium substitution (i.e., Al/Si ratio) in the C-S-H gel [26,27,29,31-34]. In Portland cements, unpolymerised isolated $\mathrm{Q}^{0}$ silicate tetrahedra (in alite and belite) appear in the range -65 to $-75 \mathrm{ppm}$, dimeric and chain-end $\mathrm{Q}^{1}$ species in the C-S-H gel resonate between -78 and $-82.5 \mathrm{ppm}$; and signals arising from mid-chain $\mathrm{Q}^{2}$ tetrahedra in the C-S-H gel have a chemical shift range of -84 to $-87.5 \mathrm{ppm}$ [34]. Substitution of $\mathrm{Al}$ for $\mathrm{Si}$ in a neighbouring tetrahedron increases the chemical shift by approximately $5 \mathrm{ppm}$, such that mid-chain $\mathrm{Q}^{2}(1 \mathrm{Al})$ species are located in the range -81 to $-83 \mathrm{ppm}$. A more detailed description of the formation, structure and analysis of the C-S-H gel phase in Portland cement-based endodontic materials is provided in reference 29.

The ${ }^{29}$ Si MAS NMR spectrum of the anhydrous cement and those of WPC and WPC-I after hydration for 7, 14 and 28 days are presented in Figure 6. The spectrum of anhydrous white Portland cement (labelled WPC in Figure 6a) features a sharp $\mathrm{Q}^{0}$ signal at $-72.5 \mathrm{ppm}$ arising from the isolated silicate tetrahedra in belite superimposed over a broad resonance in the chemical shift range -68 to $-78 \mathrm{ppm}$ from the nine crystallographically discrete $\mathrm{Q}^{0}$ silicate environments in alite that are unresolved in the MAS NMR spectra of Portland cements [35].

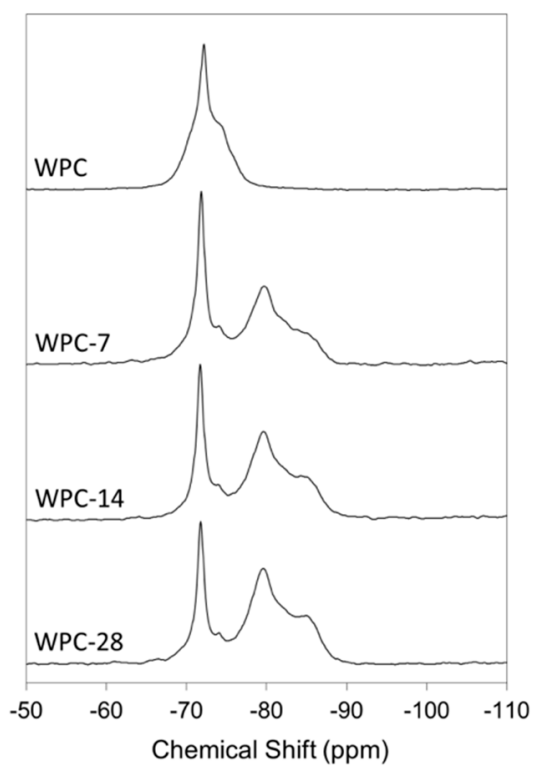

(a)

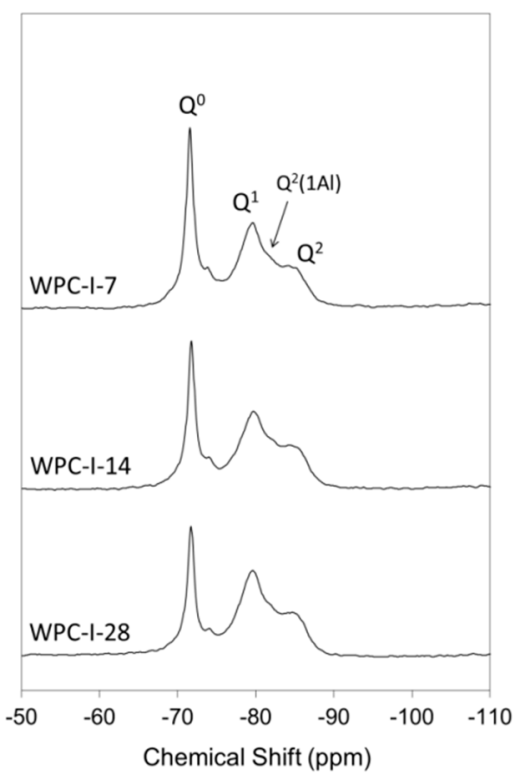

(b)

Figure 6. ${ }^{29} \mathrm{Si}$ MAS NMR spectra of (a) WPC and (b) WPC-I following hydration for 7, 14 and 28 days.

As hydration progressed, resonances corresponding to $\mathrm{Q}^{1}, \mathrm{Q}^{2}(1 \mathrm{Al})$ and $\mathrm{Q}^{2}$ species in the silicate chain structure of the C-S-H gel product began to develop at the expense of the $\mathrm{Q}^{0}$ signals from alite and belite (Figure 6). Owing to the nature of the overlapping signals from the various $\mathrm{Q}^{\mathrm{n}}$ species in hydrating Portland cements, spectral deconvolution was required prior to quantitative analysis (as outlined in Section 4.5).

The relative proportions of the various $\mathrm{Q}^{\mathrm{n}}$ species, degree of hydration, mean aluminosilicate chain length and Al/Si ratio of the C-S-H gel of WPC and WPC-I following hydration for 7, 14 and 28 days are presented in Table 1 . These data indicate that the incorporation of $20 \mathrm{wt} \%$ iodoform in the Portland cement mixture had no significant impact on the rate of hydration with respect to the development of the C-S-H gel phase, with both cements achieving a degree of hydration of $\sim 70 \%$ within 28 days. However, the mean aluminosilicate chain length of the C-S-H gel phase in WPC-I was 
shorter than that of the unblended WPC paste at 7 days, and WPC-I's Al/Si ratio was also lower than that of WPC at 14 and 28 days.

Table 1. Composition, degree of hydration, mean aluminosilicate chain length (MCL) and $\mathrm{Al} / \mathrm{Si}$ ratio of the C-S-H gel of WPC and WPC-I following hydration for 7, 14 and 28 days.

\begin{tabular}{ccccccccc}
\hline Sample & $\begin{array}{c}\text { Time } \\
\text { (Day) }\end{array}$ & $\begin{array}{c}\mathbf{Q}^{\mathbf{0}} \mathbf{( H )} \\
\mathbf{( \% )}\end{array}$ & $\mathbf{Q}^{\mathbf{1}} \mathbf{( \% )}$ & $\begin{array}{c}\mathbf{Q}^{\mathbf{2}} \mathbf{( 1 \mathbf { A l } )} \\
\mathbf{( \% )}\end{array}$ & $\mathbf{Q}^{\mathbf{2}} \mathbf{( \% )}$ & $\begin{array}{c}\text { Hydration } \\
\mathbf{( \% )}\end{array}$ & $\mathbf{M C L}$ & $\mathbf{A l} / \mathbf{S i}$ \\
\hline \multirow{3}{*}{ WPC } & 7 & 4.48 & 29.10 & 9.17 & 17.02 & 59.8 & 4.1 & 0.077 \\
& 14 & 2.23 & 40.19 & 10.25 & 15.96 & 68.6 & 3.6 & 0.075 \\
& 28 & 1.38 & 41.13 & 9.84 & 17.79 & 70.1 & 3.6 & 0.070 \\
WPC-I & 7 & 0.95 & 37.77 & 8.68 & 14.85 & 62.3 & 3.5 & 0.070 \\
& 14 & 1.06 & 39.13 & 7.08 & 19.34 & 66.6 & 3.5 & 0.053 \\
& 28 & 0.36 & 42.73 & 7.99 & 18.92 & 70.0 & 3.5 & 0.057 \\
\hline
\end{tabular}

\subsection{In Vitro Bioactivity}

Certain bioactive silicate glasses, ceramics and cements have been shown to form chemically stable, mechanically-compliant interfaces with living bone and dental tissues in vivo [24,25,37]. The interface usually develops via the precipitation of a layer of substituted hydroxyapatite $(\mathrm{HA}), \mathrm{Ca}_{5}\left(\mathrm{PO}_{4}\right)_{3}(\mathrm{OH})$, from the constituent ions in human body plasma. The HA-layer is similar in structure to the mineral component of bone and provides a focus for the attachment and growth of viable cells which then begin to regenerate the defective host tissue.

A semi-quantitative evaluation of bioactivity can be obtained in vitro by the rate of formation of a layer of HA on the surface of a material immersed in simulated body fluid (SBF), an acellular solution whose ionic concentration approximates to that of human body plasma [24]. Materials that elicit the precipitation of a superficial layer of $\mathrm{HA}$ within 4 weeks of exposure to $\mathrm{SBF}$ at $37^{\circ} \mathrm{C}$ are considered to be bioactive. Since the precipitation of HA on the surface of Portland cement-based materials is known to commence within a few hours [25], in the present study, its formation on the surface of WPC and WPC-I was monitored by FTIR after immersion in SBF for 3, 6 and $24 \mathrm{~h}$. The corresponding supernatant solution concentrations of $\mathrm{P}, \mathrm{Ca}, \mathrm{Si}$ and I were determined by ICP analysis. The concentration of phosphorus was also measured at various intervals for up to 7 days to enable the rates of HA deposition onto WPC and WPC-I to be compared using a simple kinetic model [25].

FTIR spectra of the WPC and WPC-I cements prior to and following immersion in simulated body fluid (SBF) for up to $24 \mathrm{~h}$ are presented in Figure 7 and the corresponding concentrations of $\mathrm{Ca}, \mathrm{P}$ and $\mathrm{Si}$ in the supernatant SBF liquors are plotted in Figure 8. In the FTIR spectra of WPC and WPC-I prior to immersion in SBF, stretching vibrations of the C-S-H gel gave rise to the broad combination band centred at $980 \mathrm{~cm}^{-1}$ upon which are superimposed vibrations from carbonate and sulfate groups at 870 and $1120 \mathrm{~cm}^{-1}$, respectively [25,30]. The unresolved doublet at $1490 \mathrm{~cm}^{-1}$ is attributed to calcium carbonate which formed via atmospheric carbonation of the alkaline calcium-bearing cement components. The calcium carbonate was insufficiently crystalline or abundant to be detected by XRD analysis (Figure 4). The broad bands at 3450 and $1660 \mathrm{~cm}^{-1}$ are respectively assigned to the stretching and bending modes of free and bound water within the cement matrix and also to the hydroxyl groups of the hydration products. Stretching of the non-hydrogen bonded hydroxyl group in portlandite produced the sharp signal at $3670 \mathrm{~cm}^{-1}$ in both cements, and the very weak sharp signals of iodoform are also present in the spectrum of WPC-I at 2980, 1260, 1060 and $868 \mathrm{~cm}^{-1}$. 


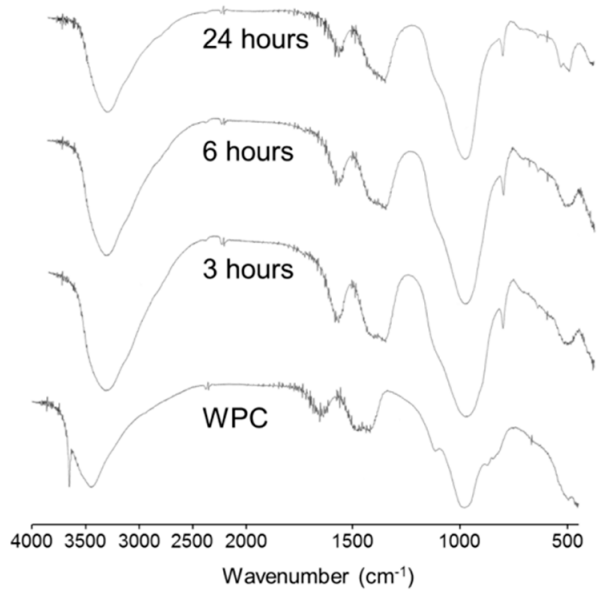

(a)

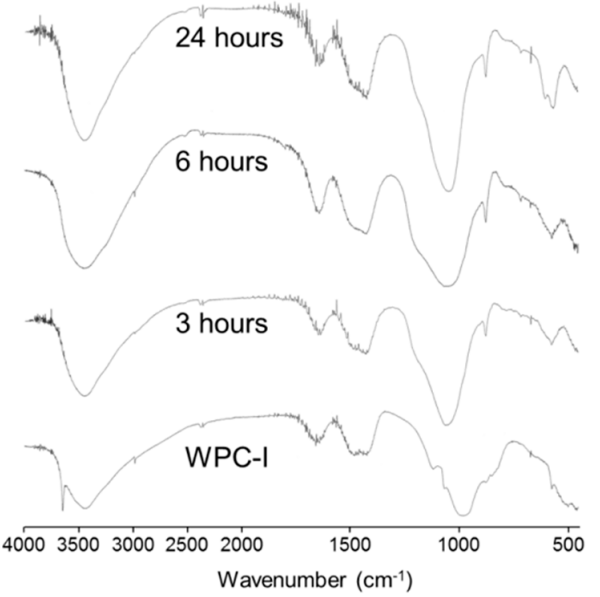

(b)

Figure 7. FTIR spectra of (a) WPC and (b) WPC-I prior to and following immersion in SBF for 3, 6 and $24 \mathrm{~h}$.

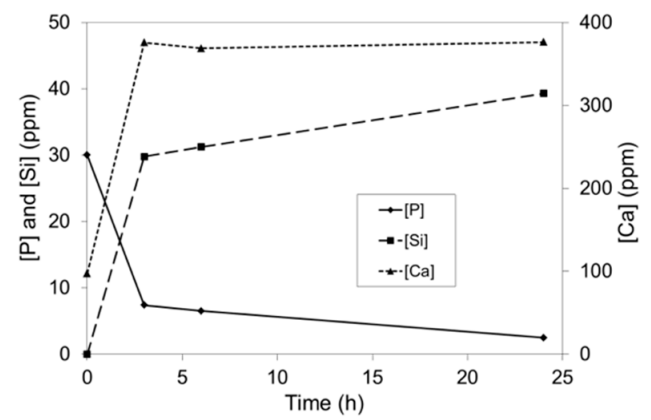

(a)

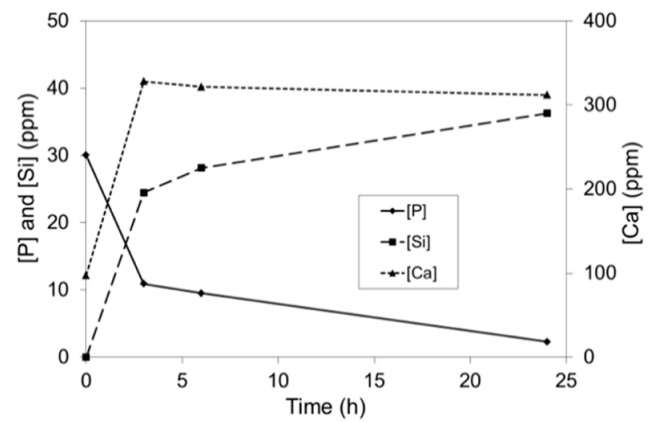

(b)

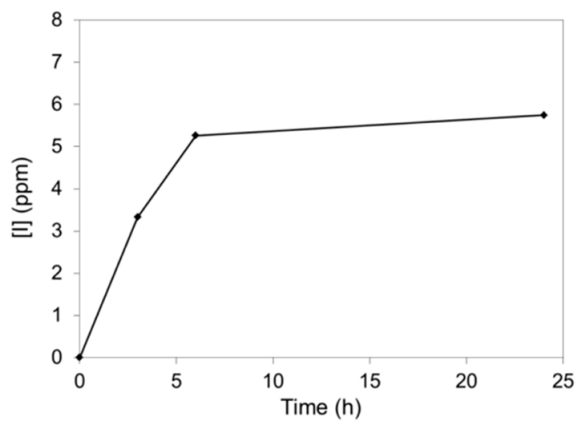

(c)

Figure 8. Concentrations of $\mathrm{Ca}, \mathrm{P}$ and $\mathrm{Si}$ in SBF as functions of residence time for (a) WPC, (b) WPC-I and (c) concentration of I released from WPC-I. 
The absence of the characteristic O-H stretching signal of portlandite at $3670 \mathrm{~cm}^{-1}$ in both WPC and WPC-I following immersion in SBF for $3 \mathrm{~h}$ denotes the rapid dissolution of this phase (Figure 7). The concomitant appearance of a P-O bending band at $\sim 600 \mathrm{~cm}^{-1}$ is indicative of the formation of amorphous hydroxyapatite which became progressively more crystalline by $24 \mathrm{~h}$, as evidenced by its partial resolution into a doublet (at 570 and $605 \mathrm{~cm}^{-1}$ ) [25]. The deposition of hydroxyapatite also broadened and shifted the Si-O stretching signal by the superposition of the P-O stretching modes at 960,1060 and $1100 \mathrm{~cm}^{-1}$ (which do not appear as discrete bands in these spectra) [25,30].

The concentrations of $\mathrm{Ca}, \mathrm{P}$ and $\mathrm{Si}$ species in the supernatant SBF solutions as functions of contact time with WPC and WPC-I are plotted in Figure 8a,b, respectively. These data are consistent with the FTIR spectra (Figure 7) and reflect the rapid dissolution of portlandite from the cement matrix and the simultaneous uptake of $\mathrm{HPO}_{4}{ }^{2-}$ ions during the precipitation of hydroxyapatite. The release of soluble silicate species was also observed from both cements within $3 \mathrm{~h}$ which continued with time. The extents of calcium and silicate dissolution from WPC were significantly higher than those of WPC-I; however, these values are not statistically different if the lower cement-content of the iodoform-blended paste is taken into consideration. The initial uptake of $\mathrm{HPO}_{4}{ }^{2-}$ ions at 3 and $6 \mathrm{~h}$ was also moderately higher for the unblended paste, although there was no difference in the $\mathrm{HPO}_{4}{ }^{2-}$ concentrations of the SBF solutions in contact with WPC and WPC-I after $24 \mathrm{~h}$. In addition to the release of calcium ions and silicate species, up to $5.8 \mathrm{ppm}$ of iodine were released from WPC-I into the SBF within $24 \mathrm{~h}$, which corresponded to $4.6 \%$ of the total iodine present in the blended cement (Figure $8 \mathrm{c}$ ). The speciation of the released iodine was not determined during this study, so it is not certain whether it is present as iodoform (which has a solubility of $100 \mathrm{ppm}$ in water), elemental iodine, free iodide ions or a combination of species.

Many calcium silicate-based bioactive glasses and ceramics exhibit an induction period on exposure to SBF prior to the deposition of hydroxyapatite which may last for several days [24,37]. During this latent stage, ion-exchange processes take place between the material and solution that increase the calcium ion concentration of the SBF and enhance its supersaturation with respect to hydroxyapatite. The dissolution of calcium ions also promotes the hydration of the silicate surface and the formation of silanol (Si-OH) bonds that provide nucleation sites for HA precipitation [37]. No such induction period is observed for Portland cement-based materials as the rapid dissolution of portlandite and abundance of pre-existing silanol groups presented by the C-S-H gel effect the efficient precipitation of hydroxyapatite $[25,30]$.

The absence of an induction period enables the application of a simple kinetic model to compare the rates of hydroxyapatite formation between different Portland cement-based materials [25]. Accordingly, the removal of $\mathrm{HPO}_{4}{ }^{2-}$ ions from the SBF solution during the precipitation of hydroxyapatite onto the surfaces of WPC and WPC-I are fitted to the simple pseudo-second-order model in Figure 9. Using this model, a linear plot of the ratio of time to uptake of solute $\left(t / q_{t}\right)$ against time indicates pseudo-second-order adsorption [25]. In both cases, the squares of the correlation coefficients, $\mathrm{R}^{2}$, are greater than 0.999 which confirms the soundness of the relationships between the experimental data points and the theoretically fitted regression curves. The apparent pseudo rate constants for WPC and WPC-I, $3.92( \pm 0.59) \times 10^{-4}$ and $2.86( \pm 0.43) \times 10^{-4} \mathrm{~g} \mathrm{mg}^{-1} \mathrm{~min}^{-1}$, respectively, are not statistically different $(p=0.066)$ indicating that the presence of $20 \mathrm{wt} \%$ iodoform had no significant impact on the in vitro bioactivity of the cement paste. This difference is even less significant if the lower cement content of the iodoform blended sample is taken into consideration. 

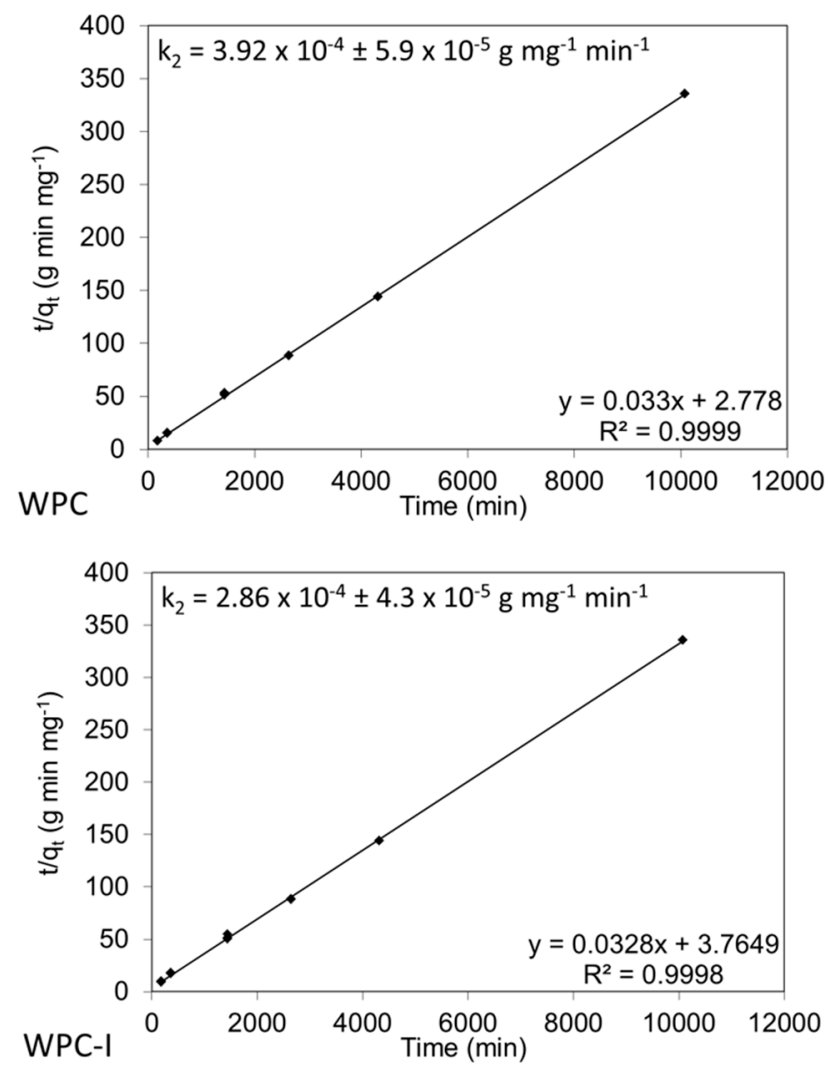

Figure 9. Pseudo-second-order model fitted to experimental data for the uptake of $\mathrm{HPO}_{4}{ }^{2-}$ ions from SBF solution during hydroxyapatite precipitation onto WPC and WPC-I.

\subsection{Antimicrobial Activity}

Microbial infection, particularly the formation of multispecies biofilms on implanted materials, is the principal cause of failure in dental treatments. Current strategies to defend dental materials from biofilm accumulation by the addition of antimicrobial additives and fillers are comprehensively reviewed in reference [38]. The microbiota of dental biofilms is exceptionally complex and, in addition to the characteristic oral microorganisms, other facultative pathogenic bacteria (e.g., S. aureus, $P$. aeruginosa and E. coli) are commonly detected in bone and dental implant-centred infections [39]. The eradication of S. aureus, P. aeruginosa and E. coli is problematic owing to their persistent biofilm forming capabilities. These microorganisms secrete a protective polysaccharide layer that defends against the immune response and antibiotic therapy, which may require surgical revision.

The results of the in vitro antibacterial assays are listed in Table 2 for control cultures of S. aureus, P. aeruginosa and E. coli and those incubated with 5, 10 or $15 \mathrm{mg}$ of cement per $\mathrm{cm}^{3}$. These data demonstrate that, by virtue of its high alkalinity, the unblended cement inhibited the growth of all three bacteria with the greatest antimicrobial effect against $E$. coli.

These data also demonstrate that the incorporation of iodoform enhanced the antimicrobial properties of the cement against both the Gram-positive (i.e., S. aureus) and Gram-negative (i.e., $P$. aeruginosa and E. coli) bacteria at 10 and $15 \mathrm{mg}$ cement $\mathrm{cm}^{-3}$ in the case of $S$. aureus, $10 \mathrm{mg}$ cement cm $\mathrm{cm}^{-3}$ for $P$. aeruginosa, and at $5 \mathrm{mg}$ cement $\mathrm{cm}^{-3}$ for E. coli (Table 2). 
Table 2. Cell viability data for control cultures and those containing WPC or WPC-I.

\begin{tabular}{|c|c|c|c|}
\hline Bacterium: Cement Concentration & Control & WPC & WPC-I \\
\hline \multicolumn{4}{|l|}{ S. aureus: $5 \mathrm{mg}$ cement $\mathrm{cm}^{-3}$} \\
\hline Mean $\left(\mathrm{cfu} \mathrm{cm} \mathrm{c}^{-3}\right)$ & $4.70 \times 10^{9}$ & $5.36 \times 10^{7}$ & $2.08 \times 10^{7}$ \\
\hline St. Dev. $\left(\mathrm{cfu} \mathrm{cm}^{-3}\right)$ & $1.43 \times 10^{9}$ & $2.83 \times 10^{7}$ & $1.45 \times 10^{7}$ \\
\hline Observed $|\mathrm{t}|$ & - & 9.63 & 8.23 \\
\hline \multicolumn{4}{|l|}{ S. aureus: $10 \mathrm{mg}$ cement $\mathrm{cm}^{-3}$} \\
\hline Mean $\left(\mathrm{cfu} \mathrm{cm}^{-3}\right)$ & $4.70 \times 10^{9}$ & $4.44 \times 10^{7}$ & $1.08 \times 10^{6}$ \\
\hline St. Dev. $\left(\mathrm{cfu} \mathrm{cm}^{-3}\right)$ & $1.43 \times 10^{9}$ & $5.10 \times 10^{6}$ & $1.45 \times 10^{5}$ \\
\hline Observed $|t|$ & - & 6.47 & 8.27 \\
\hline \multicolumn{4}{|l|}{ S. aureus: $15 \mathrm{mg}$ cement $\mathrm{cm}^{-3}$} \\
\hline Mean $\left(\mathrm{cfu} \mathrm{cm}^{-3}\right)$ & $4.70 \times 10^{9}$ & $1.68 \times 10^{5}$ & No growth \\
\hline St. Dev. $\left(\mathrm{cfu} \mathrm{cm}^{-3}\right)$ & $1.43 \times 10^{9}$ & $8.80 \times 10^{4}$ & - \\
\hline Observed $|t|$ & - & 6.53 & - \\
\hline \multicolumn{4}{|l|}{ P. aeruginosa: $5 \mathrm{mg}$ cement $\mathrm{cm}^{-3}$} \\
\hline Mean $\left(\mathrm{cfu} \mathrm{cm}^{-3}\right)$ & $1.03 \times 10^{9}$ & $3.66 \times 10^{8}$ & $8.13 \times 10^{8}$ \\
\hline St. Dev. $\left(\mathrm{cfu} \mathrm{cm}^{-3}\right)$ & $3.20 \times 10^{8}$ & $2.00 \times 10^{8}$ & $5.10 \times 10^{8}$ \\
\hline Observed $|t|$ & - & 4.5 & 0.89 \\
\hline \multicolumn{4}{|l|}{ P. aeruginosa: $10 \mathrm{mg}$ cement $\mathrm{cm}^{-3}$} \\
\hline Mean $\left(\mathrm{cfu} \mathrm{cm}^{-3}\right)$ & $1.03 \times 10^{9}$ & $2.17 \times 10^{7}$ & No growth \\
\hline St. Dev. $\left(\mathrm{cfu} \mathrm{cm}^{-3}\right)$ & $3.20 \times 10^{8}$ & $2.70 \times 10^{6}$ & - \\
\hline Observed $|t|$ & - & 8.93 & - \\
\hline \multicolumn{4}{|l|}{ P. aeruginosa: $15 \mathrm{mg}$ cement $\mathrm{cm}^{-3}$} \\
\hline Mean $\left(\mathrm{cfu} \mathrm{cm}{ }^{-3}\right)$ & $1.03 \times 10^{9}$ & No growth & No growth \\
\hline St. Dev. $\left(\mathrm{cfu} \mathrm{cm}^{-3}\right)$ & $3.20 \times 10^{8}$ & - & - \\
\hline Observed $|t|$ & - & - & - \\
\hline \multicolumn{4}{|l|}{ E. coli: $5 \mathrm{mg}$ cement $\mathrm{cm}^{-3}$} \\
\hline Mean $\left(\mathrm{cfu} \mathrm{cm}^{-3}\right)$ & $4.95 \times 10^{8}$ & $2.11 \times 10^{7}$ & No growth \\
\hline St. Dev. $\left(\mathrm{cfu} \mathrm{cm}^{-3}\right)$ & $2.26 \times 10^{8}$ & $1.77 \times 10^{7}$ & - \\
\hline Observed $|t|$ & - & 7.23 & - \\
\hline \multicolumn{4}{|l|}{ E. coli: $10 \mathrm{mg}$ cement $\mathrm{cm}^{-3}$} \\
\hline Mean $\left(\mathrm{cfu} \mathrm{cm} \mathrm{cm}^{-3}\right)$ & $4.95 \times 10^{8}$ & No growth & No growth \\
\hline St. Dev. $\left(\mathrm{cfu} \mathrm{cm}^{-3}\right)$ & $2.26 \times 10^{8}$ & - & - \\
\hline Observed $|t|$ & - & - & - \\
\hline \multicolumn{4}{|l|}{ E. coli: $15 \mathrm{mg}$ cement $\mathrm{cm}^{-3}$} \\
\hline Mean $\left(\mathrm{cfu} \mathrm{cm} \mathrm{cm}^{-3}\right)$ & $4.95 \times 10^{8}$ & No growth & No growth \\
\hline St. Dev. $\left(\mathrm{cfu} \mathrm{cm}^{-3}\right)$ & $2.26 \times 10^{8}$ & - & - \\
\hline Observed $|t|$ & - & - & - \\
\hline
\end{tabular}

Critical $|t|=2.35$ at $p=0.05$ and $(n-1)$ degrees of freedom.

The minimum inhibitory and minimum bactericidal concentration ranges for the cements with and without iodoform are summarised in Table 3. The minimum inhibitory concentration (MIC) is the lowest concentration of a substance that will inhibit the visible growth of a microorganism following overnight incubation. The minimum bactericidal concentration $(\mathrm{MBC})$ is the lowest concentration that will prevent microbial growth after subculture [40]. The MBC is also defined as the lowest concentration of a substance that reduces the viability of the initial bacterial inoculum by $>99.9 \%$, which is the criterion upon which the MBC ranges for WPC and WPC-I have been determined [40]. These data demonstrate that the incorporation of iodoform reduced the MIC range of the cement for $P$. aeruginosa and E. coli, but not for S. aureus (Table 3). Moreover, in all cases, iodoform was found to significantly reduce the MBC of the cement (Table 3). 
Table 3. Minimum inhibitory and minimum bactericidal concentration ranges for WPC and WPC-I.

\begin{tabular}{ccccc}
\hline Bacterium & & S. Aureus & P. Aeruginosa & E. Coli \\
\hline \multirow{2}{*}{ Minimum inhibitory range $\left(\mathrm{mg} \mathrm{cm}^{-3}\right)$} & WPC & $10-15$ & $10-15$ & $5-10$ \\
& WPC-I & $10-15$ & $5-10$ & $0-5$ \\
Minimum bactericidal range $\left(\mathrm{mg} \mathrm{cm}^{-3}\right)$ & WPC & $>15$ & $10-15$ & $5-10$ \\
& WPC-I & $10-15$ & $5-10$ & $0-5$ \\
\hline
\end{tabular}

\subsection{Biocompatibility}

Human osteosarcoma cells are commonly employed for the initial biocompatibility appraisal of biomaterials for dental and orthopaedic tissue treatment [41,42]. In the present study, the cytocompatibility of WPC and WPC-I towards MG63 human osteosarcoma cells was assessed using an MTT assay [41,42]. The results of this in vitro biocompatibility assessment are presented in Table 4 . These data indicate that cell viability was approximately $20 \%$ greater for the cultures incubated with WPC versus WPC-I, but this difference is not statistically significant at $p=0.05$.

Table 4. MG63 osteosarcoma MTT assay data for WPC and WPC-I.

\begin{tabular}{ccc}
\hline Property & WPC & WPC-I \\
\hline Mean Absorbance (arb) & 1.09 & 0.88 \\
Standard Deviation (arb) & 0.37 & 0.12 \\
95\% Confidence limits (arb) & \pm 0.36 & \pm 0.12 \\
Observed $|t|$ & 1.09 & \\
Critical $|t|$ & 2.35 & \\
\hline
\end{tabular}

\section{Discussion}

Portland cement-based dental materials require the addition of a radiopacifying agent to facilitate their radiographic distinction from the anatomical tissues of the tooth and periradicular structures [1-5]. Originally, $20 \mathrm{wt} \%$ bismuth oxide was added to the first commercial Portland cement-based root filling material, ProRoot ${ }^{\mathrm{TM}}$ MTA (Dentsply Sirona, York, PA, USA), to confer radiopacity. This compound is now widely acknowledged to discolour teeth, delay setting, retard hydration, and to reduce the strength and durability of the resulting cement matrix [1-5,26,29].

Iodoform is adequately biocompatible with the various dental tissues and has also seen longstanding service as an antimicrobial radiopaque admixture in calcium hydroxide and resin-based root filling and pulp capping materials [7,8,13-15,17,20-23]. Radiographic studies indicate that $20 \mathrm{wt} \%$ replacement iodoform in Portland cement formulations is sufficient to comply with the regulatory radiographic standards for root filling materials $[7,18,19,22]$, yet very little work has been carried out on the impact of iodoform on the complex hydration chemistry of the cement matrix [8].

A recent study reports that $20 \mathrm{wt} \%$ iodoform reduced the initial and final setting times of white Portland cement from 150 to $121 \mathrm{~min}$ and 200 to $165 \mathrm{~min}$, respectively [8]. Despite this finding, the current research did not identify any significant changes in heat evolution during the first $70 \mathrm{~h}$ of white Portland cement hydration in the presence of $20 \mathrm{wt} \%$ iodoform, other than a modest reduction in the exotherm arising from renewed ettringite formation (Figure 1). Initial and final setting times of Portland cements do not directly coincide with any specific chemical reactions or calorimetric events, although both setting times are anticipated to fall within the acceleration phase as the plastic cement matrix becomes rigid and begins to develop mechanical strength [28]. In this study, the reported initial and final setting times were both found to occur at the beginning of the acceleration phase (Figure 1) [8].

The reduced exotherm associated with renewed ettringite formation in the iodoform-blended cement may have arisen from the chemical incorporation of iodine species in this phase, as indicated by TEM-EDX. The TEM-EDX data showed a correlation between the I/Ca and Al/Ca molar ratios of ettringite at 3 and $6 \mathrm{~h}$ (Figure 3). This is also tentatively supported by the marked increase in the size 
of the ettringite crystals after $3 \mathrm{~h}$ in the iodoform-blended sample relative to that of the pure cement paste (Figure 2). Furthermore, the notable reduction in the relative intensity of the XRD reflections of iodoform in sample WPC-I between 7 and 28 days (Figure $4 \mathrm{~b}$ ) may also indicate that the iodoform is undergoing chemical reaction within the alkaline environment of the cement matrix. The reactivity of iodoform in the cement system is not unexpected, as halogenoalkanes are acknowledged to participate in nucleophilic substitution of the halide for hydroxide ions under mild alkaline conditions in aqueous media [43].

Despite its reactivity within the cement matrix, iodoform was found to have no impact on the rate of hydration with respect to the major C-S-H gel product phase (Table 1). However, it did reduce the substitution of $\mathrm{Al}$ for $\mathrm{Si}$ in the C-S-H structure at 14 and 28 days. Presumably, the delayed conversion of ettringite to monosulfate in the iodoform-blended cement reduced the concentration of soluble aluminate species available for incorporation into the C-S-H gel during this timeframe.

The two most common radiopacifiers in commercial Portland cement-based dental materials, zirconium oxide $\left(\mathrm{ZrO}_{2}\right)$ and bismuth oxide $\left(\mathrm{Bi}_{2} \mathrm{O}_{3}\right)$, are known to remain intact and not react or combine with any of the cement phases [29,30,44,45]. However, despite its lack of chemical reactivity, numerous studies have consistently observed that bismuth oxide prolongs setting times [9,29], retards hydration [29,44] and alters the calorimetric behaviour [29] of Portland cement. The specific mechanism of interference of $\mathrm{Bi}_{2} \mathrm{O}_{3}$ in cement hydration is not known, although it is speculated to arise from poor electrostatic interactions with the cement constituents [29]. There are conflicting reports in the literature that zirconium oxide retards [46], accelerates [45] and has no effect on the setting of Portland cements $[7,9]$. These discrepancies are attributed to differences in particle size and processing history of the $\mathrm{ZrO}_{2}$ and variations in composition and water:cement ratio of the cement formulations. Conversely, nanoparticulate $\mathrm{ZrO}_{2}$ is generally accepted to reduce setting times and accelerate hydration via a mechanism known as the 'filler effect' [47]. In spite of the chemical reactivity of iodoform, it appears to have less of an impact on the heat evolution and kinetics of hydration than the nominally inert $\mathrm{Bi}_{2} \mathrm{O}_{3}$ and $\mathrm{ZrO}_{2}$ commercial radiopacifiers.

The high alkalinity of Portland cement-based dental materials is considered to impart modest antimicrobial activity. Recent studies have been carried out to enhance the antimicrobial properties of these materials by the incorporation of antibiotic compounds such as chlorhexidine, doxycycline and cetrimide [48-51]. To date, no studies have been conducted to investigate any changes to the chemistry and microstructure of the cements in the presence of these small organic molecules, so a direct comparison with the results obtained here for the incorporation of iodoform is not currently possible. However, $0.2 \mathrm{wt} \%$ chlorhexidine is reported to have a significantly negative impact on calcified bridge formation in the direct pulp capping of dog's teeth [48]. The minimal reduction in cytocompatibility (Table 4) and bioactivity (Figures 7-9) observed for the iodoform-blended cement may represent potential advantages worthy of further histological investigation.

The specific mechanisms by which iodoform exerts microbial disinfection are unclear; although, it has been proposed that free iodine is released which oxidatively denatures bacterial proteins and also reacts with unsaturated lipids to disrupt the cell membrane [52]. A previous 'zone of inhibition' study [8] demonstrated that $20 \mathrm{wt} \%$ iodoform significantly enhanced the intrinsic antimicrobial effect of Portland cement against S. aureus, P. aeruginosa and E. coli, indicating that antimicrobial iodine species are released from the cement matrix to diffuse through the agar medium. The present research has also confirmed the release of iodine species from the blended cement in SBF (Figure 8) and has shown that the minimum bactericidal concentration of the blended cement is significantly lower than that of pure Portland cement against all three pathogens (Table 3).

From a clinical perspective, the enhanced antimicrobial activity with no significant concomitant reduction in bioactivity or cytotoxicity associated with the incorporation of iodoform in Portland cement is clearly advantageous. Whether the observed compositional changes in the AFt, AFm and $\mathrm{C}-\mathrm{S}-\mathrm{H}$ phases and ongoing dissolution of iodine species would have a significant impact on the durability of the cement matrix is unknown. Hence, some caution is warranted for long-term clinical 
applications of iodoform-blended Portland cements. This notwithstanding, a recent 24-month clinical trial with radiographic assessments on Portland cement mixed with either $20 \mathrm{wt} \% \mathrm{ZrO}_{2}$ or iodoform for primary molar pulpotomies showed no statistically significant differences in the outcomes between the two radiopacifiers indicating satisfactory clinical performance [22].

\section{Materials and Methods}

\subsection{Materials and Sample Preparation}

The oxide and calculated Bogue compositions (i.e., proportions of phases present) of the white Portland cement (ex. Lafarge, Gravesend, UK) used in this study were provided by the manufacturer and are listed in Table 5. All other reagents were purchased from Sigma-Aldrich (Gillingham, UK) and used without further purification or modification.

Table 5. Composition of white Portland cement.

\begin{tabular}{cccccc}
\hline \multicolumn{2}{c}{ Major Oxide Components } & \multicolumn{2}{c}{ Minor Oxide Components } & \multicolumn{2}{c}{ Major Crystalline Phases } \\
\hline Formula & Mass (\%) & Formula & Mass (\%) & Formula & Mass (\%) \\
\hline $\mathrm{CaO}$ & 69.2 & $\mathrm{MgO}$ & 0.49 & $\mathrm{Ca}_{3} \mathrm{SiO}_{5}$ & 65 \\
$\mathrm{SiO}_{2}$ & 25.0 & $\mathrm{P}_{2} \mathrm{O}_{5}$ & 0.43 & $\mathrm{Ca}_{2} \mathrm{SiO}_{4}$ & 22 \\
$\mathrm{Al}_{2} \mathrm{O}_{3}$ & 1.76 & $\mathrm{Fe}_{2} \mathrm{O}_{3}$ & 0.33 & $\mathrm{Ca}_{3} \mathrm{Al}_{2} \mathrm{O}_{6}$ & 4.1 \\
$\mathrm{SO}_{3}$ & 2.00 & $\mathrm{SrO}$ & 0.14 & $\mathrm{Ca}_{2}(\mathrm{Al} / \mathrm{Fe}) \mathrm{O}_{5}$ & 1.0 \\
\hline
\end{tabular}

White Portland cement (WPC) paste samples were prepared by manually mixing $10 \mathrm{~g}$ of cement with $3.5 \mathrm{~g}$ of distilled water for $5 \mathrm{~min}$ with a polypropylene spatula. Samples blended with $20 \mathrm{wt} \%$ iodoform (namely, WPC-I) were prepared similarly with partial replacement of $2 \mathrm{~g}$ of the WPC by reagent grade $\mathrm{CHI}_{3}$ at a water:solid ratio of 0.28 (i.e., a water:cement ratio of 0.35 ). The resulting pastes were sealed in polypropylene containers and cured at $37^{\circ} \mathrm{C}$ until required. Prior to analysis by powder XRD, ${ }^{27} \mathrm{Al}$ and ${ }^{29} \mathrm{Si}$ MAS NMR and FTIR, the hydration reactions were stopped by solvent exchange with propan-2-ol. This was achieved by immersion of twenty $2 \mathrm{~mm}$ fragments of the pastes in four consecutive $50 \mathrm{~cm}^{3}$ washings of propan-2-ol in a sonic bath for $30 \mathrm{~min}$. The samples were then dried to constant mass in a vacuum desiccator at room temperature.

\subsection{Isothermal Conduction Calorimetry}

The rates of heat evolution during hydration of samples WPC and WPC-I were measured by isothermal conduction calorimetry using a Thermometric 2277 TAM calorimeter (Thermometric AB, Stockholm, Sweden) at $37.5^{\circ} \mathrm{C}$ (i.e., body temperature). In triplicate, approximately $0.05 \mathrm{~g}$ of accurately weighed freshly mixed cement paste were placed in the calorimeter. Power data were collected every second for $70 \mathrm{~h}$, and the rate of heat evolution per unit gram of cement powder was then calculated by dividing the power data by the original mass of white Portland cement in the paste.

\subsection{Transmission Electron Microscopy with Energy Dispersive X-Ray Analysis}

TEM-EDX analysis of the early hydration products of WPC and WPC-I after hydration for 3 and 6 $\mathrm{h}$ at $37^{\circ} \mathrm{C}$ in sealed polypropylene containers were obtained by dispersing the sample in methanol prior to deposition onto a carbon film grid. Bright field images were obtained using a JEOL JEM200CX microscope at $200 \mathrm{kV}$ equipped with a Gata Orius SC200 digital camera (JEOL, Tokyo, Japan).

\subsection{Powder X-ray Diffraction Analysis}

Powder XRD analysis was carried out on specimens WPC and WPC-I after 7, 14 and 28 days of hydration. Diffraction patterns were obtained using a Bruker D8 diffractometer (Bruker AXS, Karlsruhe, Germany) with $\mathrm{Cu} \mathrm{K} \alpha=1.5406 \AA$, a step size of $0.019^{\circ}$ in the $2 \theta$ range from 5 to $50^{\circ}$ and a measuring 
time of $1 \mathrm{~s}$ per step. Phase identification was carried out using Powder Diffraction Files (PDF $\left.{ }^{\circledR}\right)$ on DIFFRAC.EVA software (Bruker AXS, Karlsruhe, Germany).

\section{5. ${ }^{27}$ Al and ${ }^{29}$ Si Nuclear Magnetic Resonance Spectroscopy}

${ }^{27} \mathrm{Al}$ and ${ }^{29} \mathrm{Si}$ MAS NMR spectra were collected using a JEOL JNM-ECX $300 \mathrm{MHz}$ spectrometer (JEOL (UK) Ltd., Welwyn Garden City, UK). Single pulse ${ }^{27}$ Al MAS NMR spectra were referenced to the aluminium hexaquo-ion, $\left[\mathrm{Al}\left(\mathrm{H}_{2} \mathrm{O}\right)_{6}\right]$, and obtained with a pulse delay of $0.5 \mathrm{~s}$, an acquisition time of $0.01024 \mathrm{~s}$ and 8000 scans. Single pulse ${ }^{29} \mathrm{Si}$ MAS NMR spectra were referenced to tetramethylsilane (TMS) and obtained with a pulse delay of $5 \mathrm{~s}$, an acquisition time of $0.02048 \mathrm{~s}$, and 65,000 scans. The free induction decay profiles were processed by Delta software (provided by JEOL) to obtain spectra which were then analysed using Igor Pro software (WaveMetrics Inc., Portland, OR, USA).

The ${ }^{29} \mathrm{Si}$ MAS NMR spectra were analysed by a method reported by Love et al. [31]. The signal from unreacted alite that obscures the resonances of the hydrated monomers and dimers was subtracted from the spectrum prior to deconvolution. This was accomplished by adjusting the intensity of the anhydrous WPC spectrum to match the intensity of the alite signal in the hydrated spectrum. The adjusted WPC spectrum was then subtracted from that of the hydrated sample prior to deconvolution using iterative fitting of the $\mathrm{Q}^{0}(\mathrm{H}), \mathrm{Q}^{1}, \mathrm{Q}^{2}$ and $\mathrm{Q}^{2}(1 \mathrm{Al}){ }^{29} \mathrm{Si}$ resonances to Voigt lineshapes. The concentrations of the various $\mathrm{Q}^{\mathrm{n}}$ species, degree of hydration, mean silicate chain length (MCL) and $\mathrm{Al} / \mathrm{Si}$ ratio were then calculated from the subtracted and deconvoluted spectra [32,33]. The formulae for the calculations of degree of hydration, MCL and $\mathrm{Al} / \mathrm{Si}$ ratio are given below [31,33], where $\mathrm{Q}^{\mathrm{n}}$ represents the intensity of the ${ }^{29} \mathrm{Si}$ MAS NMR signal corresponding to the relevant silicate species:

$$
\begin{gathered}
\text { Degree of hydration }=\frac{Q^{0}(H)+Q^{1}+Q^{2}+Q^{2}(1 A l)}{Q^{0}+Q^{0}(H)+Q^{1}+Q^{2}+Q^{2}(1 A l)} \times 100 \% \\
M C L=\frac{Q^{1}+Q^{2}+\frac{3}{2} Q^{2}(1 A l)}{\frac{1}{2} Q^{1}} \\
A l / S i=\frac{\frac{1}{2} Q^{2}(1 A l)}{Q^{1}+Q^{2}+Q^{2}(1 A l)}
\end{gathered}
$$

\subsection{In Vitro Bioactivity}

Simulated body fluid (SBF) was prepared in accordance with the method described in reference 24 and used immediately. $0.15 \mathrm{~g}$ of either WPC or WPC-I were contacted with $150 \mathrm{~cm}^{3}$ of SBF in hermetically sealed polypropylene containers at $37^{\circ} \mathrm{C}$ for $3,6,24,44,72$ and $168 \mathrm{~h}$. Each analysis was carried out in triplicate. Solution concentrations of $\mathrm{Ca}, \mathrm{P}, \mathrm{Si}$ and I species were analysed by inductively coupled plasma analysis optical emission spectroscopy (ICP-OES) using a TJA Iris simultaneous ICP-OES spectrometer (TJA, MA, USA) and multi-element standards matrix-matched with sodium chloride. The relative standard deviations of the means of the concentrations of the various components were less than $7 \%$. Differences in the concentrations of components in the SBF solutions in contact with WPC and WPC-I were subjected to two-tailed $t$-tests at $p=0.05$. The solid specimens were recovered by filtration after 3,6 and $24 \mathrm{~h}$, washed once with distilled water, and dried in air at $37^{\circ} \mathrm{C}$ for $24 \mathrm{~h}$ prior to analysis by FTIR using a PerkinElmer Paragon 1000 FTIR spectrophotometer to confirm the formation of a layer of hydroxyapatite. Spectra were recorded between 4000 and $500 \mathrm{~cm}^{-1}$ using pressed $\mathrm{KBr}$ discs.

The uptake of $\mathrm{HPO}_{4}{ }^{2-}$ ions during the precipitation of hydroxyapatite on the surfaces of WPC and WPC-I was modelled using the pseudo-second-order rate expression Equation (4) [25], where $k_{2}$ is 
the apparent pseudo-second-order rate constant (in $\mathrm{g} \mathrm{mg}^{-1} \mathrm{~min}^{-1}$ ), $q_{t}$ is the extent of sorption at time $t$ (in $\mathrm{mg} \mathrm{g}^{-1}$ ), and $q e$ is the extent of sorption at equilibrium (in $\mathrm{mg} \mathrm{g}^{-1}$ ):

$$
\frac{t}{q_{t}}=\frac{1}{k_{2} q_{e}^{2}}+\frac{1}{q_{e}} t
$$

Estimates of $k_{2}$ and $q_{e}$ for the uptake of $\mathrm{HPO}_{4}{ }^{2-}$ ions by WPC and WPC-I were derived from the intercept and gradient of a linear plots of $t / q_{t}$ against $t$. In both cases, the product moment correlation coefficient, $\mathrm{R}^{2}$, was estimated as an indication of goodness of fit, and the difference between $k_{2}$ values for WPC and WPC-I were tested using a two-tailed $t$-test at $p=0.05$.

\subsection{Antimicrobial Activity}

Overnight cultures of Staphylococcus aureus (NCIMB 9518), Pseudomonas aeruginosa (NCIMB 8628) and Escherichia coli (NCIMB 9001) were grown in separate McCartney bottles containing $10 \mathrm{~cm}^{3}$ of nutrient broth (Oxoid). Cement samples, WPC and WPC-I, were prepared according to the method described in Section 4.1 and cured for $6 \mathrm{~h}$ prior to grinding with a mortar and pestle and passing through a $1 \mathrm{~mm}$ sieve. WPC or WPC-I at concentrations of 50,100 and $150 \mathrm{mg}$ were added separately to McCartney bottles containing $9 \mathrm{~cm}^{3}$ of nutrient broth. These tubes were inoculated with cultures of S. aureus, P. aeruginosa or E. coli to densities of $1.9 \times 10^{5}, 9.5 \times 10^{5}$ and $4.2 \times 10^{4}$ colony forming units per $\mathrm{cm}^{3}\left(\mathrm{CFU} \mathrm{cm}{ }^{-3}\right)$, respectively. Each assay was carried out in triplicate. The cultures were then incubated, with shaking, at $37^{\circ} \mathrm{C}$ overnight and duplicate plate counts on nutrient broth (Oxoid) were taken for each assay.

\subsection{Biocompatibility}

The in vitro biocompatibilities of WPC and WPC-I were evaluated using MG63 human osteosarcoma cells (ECACC code: 86051601) as described in reference [53]. In quadruplicate, WPC and WPC-I cement samples were cast into 24-well plates and sterilised via UV irradiation for $3 \mathrm{~h}$ on each side. MG63 cells were harvested from the main culture at low-passage $(<10)$ at confluency of $80-90 \%$ and $>90 \%$ viability. They were suspended in fresh media and added to the cement-containing wells at $1 \times 10^{4}$ cells/well and $2 \mathrm{~cm}^{3}$ total volume. The cells were then incubated for $24 \mathrm{~h}$. An MTT (3-(4,5-dimethyl-2-thiazolyl)-2,5-diphenyl-2H-tetrazolium bromide) analysis was conducted to evaluate the toxicity of the cements. The original media was decanted off and $2 \mathrm{~cm}^{3}$ of fresh media were added per well. Then, $0.4 \mathrm{~cm}^{3}$ of filter-sterilised solution of $25 \mathrm{mg}$ of MTT in $50 \mathrm{~cm}^{3}$ of $0.01 \mathrm{M}$ PBS solution were placed in each well and incubated for four hours at $37^{\circ} \mathrm{C}$ and $5 \% \mathrm{CO}_{2}$. The media was decanted off, $2 \mathrm{~cm}^{3}$ of DMSO were added and the plates were incubated at room temperature for $30 \mathrm{~min}$. $0.2 \mathrm{~cm}^{3}$ of each solution was put onto a 96-well plate and the absorbance was read at $540 \mathrm{~nm}$ using a Multiskan Ascent microplate photometer plate reader (Thermoelectron Corporation, Thermoscientific, UK). The control consisted of wells with media only whose absorbance was subtracted from those of the wells containing the cements and cells. The absorbance data were subjected to a two-tailed $t$-test at $(n-2)$ degrees of freedom. The null hypothesis was tested at $p=0.05$.

\section{Conclusions}

Iodoform $\left(\mathrm{CHI}_{3}\right)$ is an alternative radiopacifier for Portland cement-based dental materials. Its impact on the setting, bioactivity, antimicrobial properties and cytotoxicity of white Portland cement were evaluated in this study. Isothermal conduction calorimetry and ${ }^{29} \mathrm{Si}$ magic angle spinning nuclear magnetic resonance spectroscopy showed that the addition of $20 \mathrm{wt} \%$ iodoform had no significant impact on the kinetics of cement hydration with respect to the formation of the major calcium silicate hydrate (C-S-H) gel product. Transmission electron microscopy with energy dispersive X-ray analysis demonstrated that iodine species were taken up by the ettringite phase. Both pure and iodoform-blended cements inhibited the growth of Staphylococcus aureus, Pseudomonas aeruginosa 
and Escherichia coli. In all cases, iodoform enhanced the antimicrobial effect and significantly reduced the minimum bactericidal concentration of the cement. Iodoform was found to have no significant adverse effects on in vitro bioactivity or cytotoxicity with respect to human MG63 osteosarcoma cells. However, from a clinical perspective, its potential reactivity and the consequent long-term stability of the cement matrix should be regarded with caution.

Author Contributions: Conceptualization, N.J.C.; methodology, N.J.C., Q.L., and A.D.D.; software, N.J.C. and Q.L.; validation, N.J.C. and Q.L.; formal analysis, N.J.C. and Q.L.; investigation, N.J.C., Q.L., and A.D.D.; resources, N.J.C.; data curation, N.J.C.; writing—original draft preparation, N.J.C.; writing-review and editing, Q.L. and A.D.D.; visualization, N.J.C.; supervision, N.J.C.; project administration, N.J.C.; funding acquisition, N.J.C. All authors have read and agreed to the published version of the manuscript.

Funding: This research received no external funding.

Acknowledgments: The authors acknowledge, with gratitude, the technical support provided by Sam Booth for the collection of the ICP data; and also Sam Lewis and Safraz Omer for the collection of the antimicrobial data.

Conflicts of Interest: The authors declare no conflict of interest.

\section{References}

1. Dawood, A.E.; Parashos, P.; Wong, R.H.K.; Reynolds, E.C.; Manton, D.J. Calcium silicate-based cements: Composition, properties, and clinical applications. J. Investig. Clin. Dent. 2017, 8, e12195. [CrossRef] [PubMed]

2. Parirokh, M.; Torabinejad, M.; Dummer, P.M.H. Mineral trioxide aggregate and other bioactive endodontic cements: An updated overview-Part I: Vital pulp therapy. Int. Endod. J. 2018, 51, 177-205. [CrossRef] [PubMed]

3. Torabinejad, M.; Parirokh, M.; Dummer, P.M.H. Mineral trioxide aggregate and other bioactive endodontic cements: An updated overview-Part II: Other clinical applications and complications. Int. Endod. J. 2018, 51, 284-317. [CrossRef] [PubMed]

4. Prati, C.; Gandolfi, M.G. Calcium silicate bioactive cements: Biological perspectives and clinical applications. Dent. Mater. 2015, 31, 351-370. [CrossRef]

5. Ha, W.N.; Nicholson, T.; Kahler, B.; Walsh, L.J. Mineral trioxide aggregate-A review of properties and testing methodologies. Materials 2017, 10, 1261. [CrossRef]

6. International Organization for Standardization. ISO 6876:2012 Dental Root Canal Sealing Materials, 3rd ed.; International Organization for Standardization: Geneva, Switzerland, 2012.

7. Antonijevic, D.; Medigovic, I.; Zrilic, M.; Jokic, B.; Vukovic, Z.; Todorovic, L. The influence of different radiopacifying agents on the radiopacity, compressive strength, setting time, and porosity of Portland cement. Clin. Oral Investig. 2014, 18, 1597-1604. [CrossRef]

8. Coleman, N.J.; Li, Q. The impact of iodoform on the hydration, bioactivity and antimicrobial properties of white Portland cement. MATEC Web Conf. 2017, 109, 04002. [CrossRef]

9. Coleman, N.J.; Hanarasinghe, R.; Güçlü, Z.A.; Booth, S.E. In vitro bioactivity and setting times of white Portland cement combined with different radio pacifying agents. MATEC Web Conf. 2017, 109, 03003. [CrossRef]

10. Cost, B.C.; Guerreiro-Tanomaru, J.M.; Bosso-Martelo, R.; Rodrigues, E.M.; Bonetti-Filho, I.; Tanomaru-Filho, M. Ytterbium oxide as radiopacifier of calcium silicate-based cements. Physicochemical and biological properties. Braz. Dent. J. 2018, 29, 452-458. [CrossRef]

11. Elsaka, S.E.; Elnaghy, A.M.; Mandorah, A.; Elshazli, A.H. Effect of titanium tetrafluoride addition on the physicochemical and antibacterial properties of Biodentine as intraorfice barrier. Dent. Mater. 2019, 35, 185-193. [CrossRef]

12. Ochoa-Rodríguez, V.M.; Tanomaru-Filho, M.; Rodrigues, E.M.; Guerreiro-Tanomaru, J.M.; Spin-Neto, R.; Faria, G. Addition of zirconium oxide to Biodentine increases radiopacity and does not alter its physicochemical and biological properties. J. Appl. Oral Sci. 2019, 27, e20180429. [CrossRef] [PubMed]

13. Rai, R.; Shashibhusan, K.K.; Babaji, P.; Chandrappa, P.M.; Reddy, V.R.; Ambareen, Z. Clinical and radiographic evaluation of 3Mix and Vitapex as pulpectomy medicament in primary molars: An in vivo study. Int. J. Clin. Pediatr. Dent. 2019, 12, 532-537. [PubMed] 
14. Navit, S.; Jaiswal, N.; Khan, S.A.; Malhotra, S.; Sharma, A.; Mukesh; Jabeen, S.; Agarwal, G. Antimicrobial efficacy of contemporary obturating materials used in primary teeth- an in-vitro study. J. Clin. Diagn. Res. 2016, 10, 9-12.

15. Brezhnev, A.; Neelakantan, P.; Tanaka, R.; Brezhnev, S.; Fokas, G.; Matinlinna, J.P. Antibacterial additives in epoxy resin-based root canal sealers: A focused review. Dent. J. 2019, 7, 72. [CrossRef]

16. American National Standards Institute/American Dental Association. ANSI/ADA Specification 57: Endodontic Sealing Material; American National Standards Institute/American Dental Association: Chicago, IL, USA, 2000.

17. De Morais, C.A.H.; Bernardineli, N.; Garcia, R.B.; Duarte, M.A.H.; Guerisoli, D.M.Z. Evaluation of tissue response to MTA and Portland cement with iodoform. Oral Surg. Oral Med. Oral Pathol. Oral Radiol. Endod. 2006, 102, 417-421. [CrossRef]

18. Bortoluzzi, E.A.; Guerreiro-Tanomaru, J.M.; Tanomaru-Filho, M.; Duarte, M.A.H. Radiographic effect of different radiopacifiers on a potential retrograde filling material. Oral Surg. Oral Med. Oral Pathol. Oral Radiol. Endod. 2009, 108, 628-632. [CrossRef]

19. Duarte, M.A.H.; El Kadre, G.D.D.; Vivan, R.R.; Guerreiro-Tanomaru, J.M.; Tanomaru-Filho, M.; de Moraes, I.G. Radiopacity of Portland cement associated with different radiopacifying agents. J. Endod. 2009, 35, 737-740. [CrossRef]

20. Lourenço Neto, N.; Marques, N.C.T.; Fernandes, A.P.; Rodini, C.O.; Duarte, M.A.H.; Lima, M.C.; Machado, M.A.A.M.; Abdo, R.C.C.; Oliviera, T.M. Biocompatibility of Portland cement combined with different radiopacifying agents. J. Oral. Sci. 2014, 56, 29-34. [CrossRef]

21. Marques, N.; Lourenço Neto, N.; Fernandes, A.P.; Rodini, C.; Hungaro Duarte, M.; Rios, D.; Machado, M.A.; Oliviera, T. Pulp tissue response to Portland cement associated with different radio pacifying agents on pulpotomy of human primary molars. J. Microscopy 2015, 260, 281-286. [CrossRef]

22. Lourenço Neto, N.; Marques, N.C.T.; Fernandes, A.P.; Hungaro Duarte, M.A.; Abdo, R.C.C.; Machado, M.A.A.M.; Oliveira, T.M. Clinical and radiographic evaluation of Portland cement added to radiopacifying agents in primary molar pulpotomies. Eur. Arch. Paediatr. Dent. 2015, 16, 377-382. [CrossRef]

23. Sabari, M.H.; Kavitha, M.; Shobana, S. Comparative evaluation of tissue response of MTA and Portland cement with three radiopacifying agents: An animal study. J. Contemp. Dent. Pract. 2019, 20, $20-25$. [PubMed]

24. Kokubo, T.; Takadama, H. How useful is SBF in predicting in vivo bone bioactivity? Biomaterials 2006, 27, 2907-2915. [CrossRef] [PubMed]

25. Coleman, N.J.; Awosanya, K.; Nicholson, J.W. Aspects of the in vitro bioactivity of hydraulic calcium (alumino)silicate cement. J. Biomed. Mater. Res. 2009, 90, 166-174. [CrossRef]

26. Li, Q.; Coleman, N.J. The hydration chemistry of ProRoot MTA. Dent. Mater. J. 2015, 34, 458-465. [CrossRef]

27. Li, Q.; Hurt, A.P.; Coleman, N.J. The application of ${ }^{29} \mathrm{Si}$ NMR spectroscopy to the analysis of calcium silicate-based cement using Biodentine ${ }^{\mathrm{TM}}$ as an example. J. Funct. Biomater. 2019, 10, 25. [CrossRef] [PubMed]

28. Gartner, E.M.; Young, J.F.; Damidot, D.A.; Jawed, I. Hydration of Portland cement. In Structure and Performance of Cements, 2nd ed.; Bensted, J., Barnes, P., Eds.; Spon Press: London, UK, 2002; pp. 57-113.

29. Li, Q.; Coleman, N.J. Impact of $\mathrm{Bi}_{2} \mathrm{O}_{3}$ and $\mathrm{ZrO}_{2}$ radiopacifiers on the early hydration and C-S-H gel structure of white Portland cement. J. Funct. Biomater. 2019, 10, 46. [CrossRef] [PubMed]

30. Li, Q.; Coleman, N.J. Hydration kinetics, ion-release and antimicrobial properties of white Portland cement blended with zirconium oxide nanoparticles. Dent. Mater. J. 2014, 33, 805-810. [CrossRef]

31. Love, C.A.; Richardson, I.G.; Brough, A.R. Composition and structure of C-S-H in white Portland cement-20\% metakaolin pastes hydrated at $25^{\circ} \mathrm{C}$. Cem. Concr. Res. 2007, 37, 109-117. [CrossRef]

32. Justnes, H.; Meland, I.; Bjoergum, O.; Krane, J.; Skjetne, T. Nuclear magnetic resonance-A powerful tool in cement and concrete research. Adv. Cem. Res. 1990, 3, 105-110. [CrossRef]

33. Andersen, M.D.; Jakobsen, H.J.; Skibsted, J. Characterization of white Portland cement hydration and the C-S-H structure in the presence of sodium aluminate by ${ }^{27} \mathrm{Al}$ and ${ }^{29} \mathrm{Si}$ MAS NMR spectroscopy. Cem. Concr. Res. 2004, 34, 857-868. [CrossRef]

34. Engelhardt, G.; Michel, D. High-Resolution Solid State NMR of Silicates and Zeolites; John Wiley \& Sons: Chichester, UK, 1987. 
35. Skibsted, J.; Jakobsen, H.J.; Hall, C. Direct observations of aluminium guest ions in the silicate phases of cement minerals by 27Al MAS NMR spectroscopy. J. Chem. Soc. Faraday Trans. 1994, 90, 2095-2098. [CrossRef]

36. Andersen, M.D.; Jakobsen, H.J.; Skibsted, J. A new aluminium-hydrate species in hydrated Portland cements characterized ${ }^{27} \mathrm{Al}$ and ${ }^{29} \mathrm{Si}$ MAS NMR spectroscopy. Cem. Concr. Res. 2006, 36, 3-17. [CrossRef]

37. Coleman, N.J.; Bellantone, M.; Nicholson, J.W.; Mendham, A.P. Textural and structural properties of bioactive glasses in the system $\mathrm{CaO}-\mathrm{SiO}_{2}$. Ceramics-Silikáty 2007, 51, 1-8.

38. Makvandi, P.; Ting Gu, J.; Nazarzadeh Zare, E.; Ashtari, B.; Moeini, A.; Tay, F.R.; Niu, L. Polymeric and inorganic nanoscopical antimicrobial fillers in dentistry. Acta Biomater. 2020, 101, 69-101. [CrossRef]

39. Pye, A.D.; Lockhart, D.E.A.; Dawson, M.P.; Murray, C.A.; Smith, A.J. A review of dental implants and infection. J. Hosp. Infect. 2009, 72, 104-110. [CrossRef]

40. Andrews, J.M. Determination of minimum inhibitory concentrations. J. Antimicrob. Chemother. 2001, 48, 5-16. [CrossRef]

41. Turco, G.; Porrelli, D.; Marsich, E.; Vecchies, F.; Lombardi, T.; Stacchi, C.; Di Lenarda, R. Three-dimensional bone substitutes for oral and maxillofacial surgery: Biological and structural characterization. J. Funct. Biomater. 2018, 9, 62. [CrossRef]

42. Ruiz-Clavijo, A.; Hurt, A.P.; Kotha, A.K.; Coleman, N.J. Effect of calcium precursor on the bioactivity and biocompatibility of sol-gel-derived glasses. J. Funct. Biomater. 2019, 10, 13. [CrossRef]

43. Clayden, J.; Greeves, N.; Warren, S. Organic Chemistry, 2nd ed.; Oxford University Press: Oxford, UK, 2012.

44. Li, Q.; Coleman, N.J. Early hydration of white Portland cement in the presence of bismuth oxide. Adv. Appl. Ceram. 2013, 112, 207-212. [CrossRef]

45. Coleman, N.J.; Li, Q. The impact of zirconium oxide radiopacifier on the early hydration behavior of white Portland cement. Mater. Sci. Eng. C 2013, 33, 427-433. [CrossRef]

46. Silva, G.F.; Bosso, R.; Ferino, R.V.; Tanomaru-Filho, M.; Bernardi, M.I.B.; Guerreiro-Tanomaru, J.M.; Cerri, P.S. Microparticulated and nanoparticulated zirconium oxide added to calcium silicate cement: Evaluation of physicochemical and biological properties. J. Biomed. Mater. Res. Part. A 2014, 102, 4336-4345. [CrossRef] [PubMed]

47. Wang, J.; Han, B.; Li, Z.; Yu, X.; Dong, X. Effect investigation of nanofillers on C-S-H gel structure with Si NMR. J. Mater. Civ. Eng. 2019, 31. [CrossRef]

48. Manochehrifar, H.; Parirokh, M.; Kakooei, S.; Oloomi, M.M.; Asgary, S.; Eghbal, M.J.; Abbas, F.M. The effect of mineral trioxide aggregate mixed with chlorhexidine as direct pulp capping agent in dogs teeth: A histologic study. Iran Endod. J. 2016, 11, 320-324. [PubMed]

49. Nikhil, V.; Madan, M.; Agarwal, C.; Suri, N. Effect of addition of $2 \%$ chlorhexidine or $10 \%$ doxycycline on antimicrobial activity of biodentine. J. Conserv. Dent. 2014, 17, 271-275. [CrossRef]

50. Suri, N.K.; Nikhil, V.; Jha, P.; Jaiswal, S. Evaluation of effect of addition of $2 \%$ chlorhexidine on the sealing ability of Biodentine: An in vitro study. J. Conserv. Dent. 2015, 18, 479-482.

51. Deveci, C.; Tüzüner, T.; Cinar, C.; Odabas, M.E.; Buruk, C.K. Short-term antibacterial activity and compressive strength of Biodentine containing chlorhexidine/cetirimide mixtures. Niger J. Clin. Pract. 2019, 22, 227-231.

52. Darvell, B.W. Materials Science for Dentistry, 10th ed.; Woodhead Publishing: Cambridge, UK, 2018; pp. 771-789.

53. Li, Q.; Deacon, A.D.; Coleman, N.J. The impact of zirconium oxide nanoparticles on the hydration chemistry and biocompatibility of white Portland cement. Dent. Mater. J. 2013, 32, 808-815. [CrossRef]

(C) 2020 by the authors. Licensee MDPI, Basel, Switzerland. This article is an open access article distributed under the terms and conditions of the Creative Commons Attribution (CC BY) license (http://creativecommons.org/licenses/by/4.0/). 